\title{
Use of STAT-Flame AAS for the Determination of Lead and Cadmium Pollution in Urban Center
}

\author{
Nagihan M. Karaaslan and Mehmet Yaman* \\ Firat University, Sciences Faculty, Department of Chemistry, \\ Elazig, Turkey
}

\section{INDRODUCTION}

It has been reported that lead $(\mathrm{Pb})$ and cadmium $(\mathrm{Cd})$ accumulation in the human body can cause health risks and adversely affect physiological functions such as the brain, kidneys, the reproductive system, and intellectual functions (1-3). The World Health Organization (WHO) (4) provides guidelines with regard to tolerable amounts of these elements and established provisional tolerable weekly intake (PTWIs) of $\mathrm{Pb}$ and $\mathrm{Cd}$ at 0.025 and $0.007 \mathrm{mg} \mathrm{kg}^{-1}$ body weight, respectively. It has been reported that the absorption rates of $\mathrm{Pb}$ and $\mathrm{Cd}$ by inhalation are significantly higher (50-60\%) than by ingestion (3-10\%) (5). Thus, the determination of these elements in the air is more important than in other environmental matrices. However, few of these studies are available because it is difficult to obtain air samples, and the concentration of these metals in an aerial matrix is very low. As a result, plant parts such as leaves, shoots, and bark have been used for biomonitoring purposes (6-15) and, therefore, proper selection of plant species plays an important role. These types of samples can establish the source of metal emissions and verify overland transportation of the individual elements (7-10). Kaya et al. (16) reported that the leaves from Pinus Nigra L., growing near a lead battery factory, contained $\mathrm{Pb}$ concentrations above $3.000 \mathrm{mg} \mathrm{kg}^{-1}$.

*Corressponding author

E-mail: myaman@firat.edu.tr

Tel: 904242370000

Fax: 904242330062

\begin{abstract}
Lead $(\mathrm{Pb})$ and cadmium $(\mathrm{Cd})$ concentrations in Pinus Nigra L., Cedrus Libani, and Cupressus Arizonica plants were determined for biomonitoring of environmental pollution in Elazig, Turkey. For this purpose, leaves from these plant species together with soil samples were collected from various locations during different months of the year.

The samples were digested using the dry ashing method. For the determinations, an on-line method was applied using slotted tube atom trap-flame atomic absorption spectrometry (STATFAAS) which is fast, involves low risk of contamination, and low cost. The results obtained were evaluated based on traffic density, industrial factories, population, and seasonal variation.

Lead and Cd concentrations were found to range from 139 to $768 \mu \mathrm{g} \mathrm{kg}^{-1}$ and $<$ LOD-57 $\mu \mathrm{g} \mathrm{kg}^{-1}$ for Pinus Nigra L., 113 to $908 \mu \mathrm{g}$ $\mathrm{kg}^{-1}$ and 9 to $55 \mu \mathrm{g} \mathrm{kg}^{-1}$ for Cedrus Libani, and 88 to $813 \mu \mathrm{g}$ $\mathrm{kg}^{-1}$ and $<\mathrm{LOD}-50 \mu \mathrm{g} \mathrm{kg}^{-1}$ for Cupressus Arizonica, respectively. The levels observed for $\mathrm{Pb}$ and $\mathrm{Cd}$ in the soils ranged from 3100-10112 $\mu \mathrm{g} \mathrm{kg}^{-1}$ and 106$505 \mu \mathrm{g} \mathrm{kg}^{-1}$, respectively.
\end{abstract}

Kaya and Yaman (9) found $\mathrm{Pb}$ concentrations higher than $5.000 \mathrm{mg} \mathrm{kg}^{-1}$ in leaves from Cupressus Arizonica also growing near a lead battery plant.

In addition to occupational exposure, humans are exposed to $\mathrm{Pb}$ and $\mathrm{Cd}$ through food and air. It has been reported that $\mathrm{Pb}$ exposure of school-aged children can significantly reduce their IQ and has also been associated with aggressive behavior, delinquency, and attention disorders (1). Cadmium competes with zinc $(\mathrm{Zn})$ for binding sites and can therefore interfere with some of zinc's essential functions. Thus, it may inhibit enzyme reactions and utilization of nutrients. Cadmium can generate free radical tissue damage because it may be a catalyst to oxidation reactions. Furthermore, excessive Cd exposure can cause renal damage, reproduction problems, cardiovascular diseases, and hypertension. The frequently observed toxic effect of Cd in humans is chronic nephropathy characterized by proximal tubular necrosis and proteinurea (2). The International Agency Research on Cancer (IARC) reported that inhalation of $\mathrm{Cd}$ can cause lung cancer in humans and animals (17). Other sources of $\mathrm{Cd}$ exposure include employment in primary metal industries, production of certain batteries, electroplating processes, and use of tobacco products. Lead is also used in hundreds of products such as pipes, solder, brass fixtures, crystal, paint, cable, ceramics, and batteries due to its malleability, low melting point, and the ability to form compounds. The population of at least 100 countries is still exposed to considerable $\mathrm{Pb}$ levels owing to air pollution caused by leaded gasoline despite its ban.

Due to low concentrations of toxic trace metals such as $\mathrm{Pb}$ and $\mathrm{Cd}$, analytical techniques with high sensitivity are required for detection of these metals. These techniques include electrothermal atomic absorption spectrometry (ETAAS), inductively coupled 
plasma-atomic emission spectrometry (ICP-AES) and inductively coupled plasma-mass spectrometry (ICP-MS).

It is well known that flameless atomic absorption spectrometry is a more sensitive technique than flame atomic absorption spectrometry (FAAS). However, relative to the latter technique, some of the disadvantages associated with flameless AAS are high cost, slow speed, and being prone to interferences (10). Effective chemical modifiers, background correction systems, improved furnace and platform designs, and careful optimization of temperature programs are used to remove the interferences in flameless AAS analysis. However, FAAS is still considered the preferred method because FAAS is faster, less expensive, and does not require expert operators.

In recent times, $\mathrm{Cd}, \mathrm{Pb}$, and $\mathrm{Cu}$ concentrations in biological and environmental sample, have been determined by slotted tube atom trap-flame atomic absorption spectrometry (STAT-FAAS) with or without preconcentration methods. In those studies, 7- and 13-fold improvements in the sensitivity of FAAS in conjunction with the appli- cation of STAT were achieved for $\mathrm{Pb}$ and $\mathrm{Cd}$ determination.

In this study, we propose the use of STAT-FAAS to determine Cd and $\mathrm{Pb}$ in leaf and soil samples from urban areas in Elazig, Turkey. In one of the studied areas, there is a cement factory which has been operating for 50 years. Consideration was also given to regions with heavy traffic and population density. In addition to collecting plant and soil samples from different sites, we also established a control location away from the city center. Three plant species (Pinus Nigra L., Cedrus Libani, and Cupressus Arizonica), which are evergreen needle conifer tress, were selected to determine the atmospheric pollution of the areas.

\section{EXPERIMENTAL}

\section{Sampling}

The six sampling sites in the center of Elazig city (population of 322,000 ), including an urban control area selected for this study, are shown in Figure 1. The results obtained were evaluated based on heavy traffic, type of factory, population density, and seasonal variation. Sampling was conducted during the months of July, November, and December 2008 and

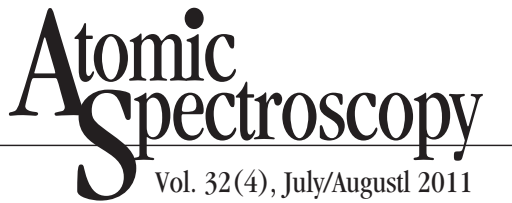

March 2009. The plant species (angiosperm), Pinus Nigra L., Cedrus Libani, and Cupressus Arizonica, were planted many years ago and are of about the same age. Healthy looking leaves (about $100 \mathrm{~g}$ of fresh and new leaves) were taken from the top points (about 2-3 $\mathrm{m}$ above the ground) of the three types of trees at each location. The samples were homogenously mixed, put into dry plastic containers, and covered. Azcue and Mudroch (18) suggest that the best cleaning method for studies of multi-element concentrations in vegetation is washing thoroughly with distilled water. In our laboratory, the samples were rinsed with tap water, scrubbed by hand to completely remove the dust, and then rinsed with distilled water. The soil samples were taken from around the sample trees at a depth of $10.0 \mathrm{~cm}$ and at a distance of $2.0 \mathrm{~m}$.

\section{INSTRUMENTATION}

The $\mathrm{Cd}$ and $\mathrm{Pb}$ concentrations were determined using a Model ATI UNICAM 929 flame atomic absorption spectrometer (Unicam Ltd., Cambridge, England). The optimum instrumental conditions for $\mathrm{Pb}$ and Cd were applied as described in the FAAS handbook and are listed in Table I.

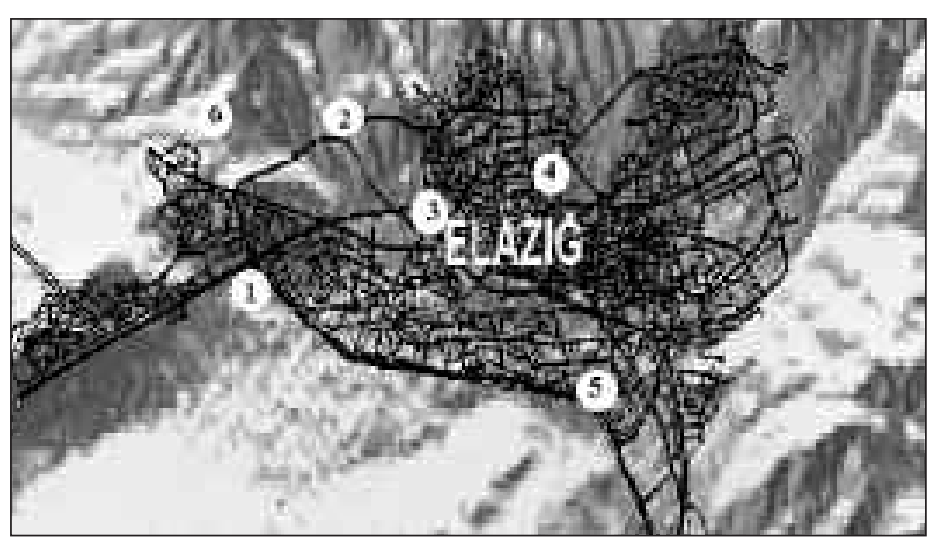

Fig. 1. Map of sampling locations: $1=$ Cayda Cira (traffic intersection), 2 = University, 3 = Province (city center), $4=$ Ordu Evi (city center), $5=$ Cement factory location, $6=$ Control area (away from residential areas and factories).
TABLE I

Instrumental Operating Conditions of ATI UNICAM 929 FAAS

\begin{tabular}{lrc} 
Parameter & \multicolumn{1}{c}{$\mathrm{Pb}$} & \multicolumn{1}{c}{$\mathrm{Cd}$} \\
Wavelength $(\mathrm{nm})$ & 217.0 & 228.8 \\
HCL current (mA) & 9.5 & 4.0 \\
Acetylene flow rate (L/min) & 0.6 & 0.6 \\
Air flow rate (L/min) & 4.0 & 4.0 \\
Slit (nm) & 0.5 & 0.5 \\
\hline
\end{tabular}


A quartz slotted tube atom trap (STAT) (Quarzschmelze Ilmenau Gmbh, Ilmenau, Germany) was used to enhance the sensitivity of FAAS analysis. The tube was slightly modified in a local glass workshop $(10,19)$ to the measurements as listed in Table II.

\section{Standard Solutions and Reagents}

The standard solutions (1000 $\mathrm{mg} \mathrm{L}^{-1}$ ) of $\mathrm{Pb}$ and $\mathrm{Cd}$ were prepared from their nitrate salts (Merck, Darmstadt, Germany). Nitric acid (65\%, Merck) and hydrogen peroxide (35\%, Merck) were used for digestion of the samples. All chemicals used were of analytical reagent grade. Double distilled water obtained with a water purification system (Millipore ${ }^{\circledR}$ Direct-Q, Millipore Corporation, Bedford, MA, USA) was used for all preparations. When not in use, all Pyrex ${ }^{\circledR}$ glassware was kept permanently full of $1 \mathrm{~mol} / \mathrm{L}$ nitric acid.

\section{Sample Preparation and $\mathrm{Pb}$ and Cd Determination in Leaves and Soils}

The leave samples (about $100 \mathrm{~g}$ of fresh and new leaves) were homogenously mixed. After drying to constant weight at $70{ }^{\circ} \mathrm{C}$, three separate portions of the sub-sample from the mixed samples described above from each of the plants Pinus Nigra L., Cedrus Libani, and Cupressus Arizonica were prepared for the ashing procedure. Sample amounts of $0.2-2.0 \mathrm{~g}$ (depending on the metal concentrations in the matrix) were transferred into Pyrex ${ }^{\circledR}$ flasks and digested using the dry ashing procedure. As a result, each of the samples was analyzed in triplicate and the average of three values was used as the mean value on a dryweight basis.

Sample digestion procedures should be safe and simple, use a short digestion time, have minimal risk for contamination during sam-

Table II

Conditions for the Quartz Tube in the Slotted Tube Atom Trap $(10,19)$

\begin{tabular}{lll}
\hline Parameters & $\mathrm{Pb}$ & $\mathrm{Cd}$ \\
\hline Diameter of tube & $6 \mathrm{~mm}$ & $6 \mathrm{~mm}$ \\
Length of upper slot & $1 \mathrm{~cm}$ & $1 \mathrm{~cm}$ \\
Length of tube & $12 \mathrm{~cm}$ & $12 \mathrm{~cm}$ \\
Improvement in the sensitivity & 7 -fold & 13 -fold \\
Length of the lower slot & $5 \mathrm{~cm}$ & $5 \mathrm{~cm}$ \\
Tube thickness & $1.5 \mathrm{~mm}$ & $1.5 \mathrm{~mm}$
\end{tabular}

ple handling, and recover the total amount of the trace elements in plant tissue $(16,20,21)$. Although wet and dry ashing procedures have been used by a number of researchers, each procedure has its shortcomings. For example, some elements such as $\mathrm{As}, \mathrm{Cr}$, and $\mathrm{Pb}$ may be lost at ashing temperatures of $500-550{ }^{\circ} \mathrm{C}(20)$. Thus, lower ashing temperatures of $400-450{ }^{\circ} \mathrm{C}$ are advisable, but these often are not sufficient for ashing of some plant tissues and require repetitive sample heating and acid treatment. This in turn increases the risk of sample contamination.

Taking these points into consideration for dry ashing of the leaves, the dried samples were heated gradually in a furnace using the following sequence: at $250^{\circ} \mathrm{C}$ for 30 minutes, at $300{ }^{\circ} \mathrm{C}$ for 5 minutes, at $350{ }^{\circ} \mathrm{C}$ for 5 minutes, at $400{ }^{\circ} \mathrm{C}$ for 5 minutes, at $450{ }^{\circ} \mathrm{C}$ for about 20 minutes to finish gas formation, and ashed at $480^{\circ} \mathrm{C}$ for 4 hours. The mixture $(1 / 1)$ of concentrated $\mathrm{HNO}_{3} / \mathrm{H}_{2} \mathrm{O}_{2}(3 \mathrm{~mL}$ for $1 \mathrm{~g}$ of dried sample) was added to the ashed sample and then evaporated to near dryness with occasional stirring. This procedure was repeated once again. After cooling, $3.0 \mathrm{~mL}$ of 1.0 $M$ nitric acid was added, and the samples were centrifuged, if necessary. The clear solutions were analyzed by STAT-FAAS for $\mathrm{Pb}$ and $\mathrm{Cd}$. In addition, blank samples were prepared and analyzed using the same procedure. The limits of detection (LODs) for the plants were found to be $0.050 \mathrm{mg} \mathrm{kg}^{-1}$ for $\mathrm{Pb}$ and 0.005 $\mathrm{mg} \mathrm{kg}^{-1}$ for Cd using $2 \mathrm{~g}$ of dried sample and $3 \mathrm{~mL}$ of final solution.

The soil samples were dried at $100{ }^{\circ} \mathrm{C}$, then 0.2 -g portions were transferred into the flasks, and $2.0 \mathrm{~mL}$ of the concentrated $(1 / 1)$ $\mathrm{HNO}_{3} / \mathrm{H}_{2} \mathrm{O}_{2}$ mixture was added. This solution was evaporated to near dryness using occasional stirring. This procedure was repeated once again. After cooling, $3.0 \mathrm{~mL}$ of 1.0 $\mathrm{M} \mathrm{HNO}_{3}$ was added, mixed and centrifuged to bring the released metals into solution. The clear solution was analyzed using STAT-FAAS for $\mathrm{Pb}$ and $\mathrm{Cd}$ determination. Blank samples were also prepared and analyzed using the same procedure. The results are given on a dryweight basis. The LODs for the soils were found to be $0.50 \mathrm{mg} \mathrm{kg}^{-1}$ for $\mathrm{Pb}$ and $0.05 \mathrm{mg} \mathrm{kg}^{-1}$ for Cd using $0.2 \mathrm{~g}$ of dried sample and $3 \mathrm{~mL}$ of final solution. As a result, each of the samples was analyzed in triplicate, and the average of three values of the same sample was used as the mean value. 


\section{Atomic Apectroscopy \\ 1 Vol. 32(4), July/Augustl 2011}

\section{Calibration Curves}

Calibration curves were obtained by using the solutions of the studied elements at different concentrations. The obtained curves (Figures 2-3) were linear in the concentration ranges described below; the equations of the curves were as follows:

$y=0.306 x-0.0734 \quad R^{2}=0.9998$ for Pb by STAT (30-400 $\mathrm{ng} \mathrm{mL} \mathrm{mL}^{-1}$ )

$\mathrm{y}=3.1284 \mathrm{x}+0.3547 \quad \mathrm{R}^{2}=0.9999$ for Cd by STAT (3.0-40.0 $\mathrm{ng} \mathrm{mL}^{-1}$ )

One-way Analysis of Variance (ANOVA) was used for the statistical evaluation of the results.

\section{RESULTS}

\section{Analytical Performance}

It is known that there are three methods to check the reliability of the analytical results obtained: (a) Use of a Standard Reference Material (SRM), (b) comparison of the results with the results obtained by the independent method for the same samples, and (c) the recovery test (16).

In this study, two methods were applied to check the accuracy of the results. Firstly, the accuracy of the method was checked by using Standard Reference Material NCSDC73348 Bush Branches and Leaves (obtained from China National Analysis Center). The recoveries were found to be $96 \%$ for $\mathrm{Pb}$ and $93 \%$ for $\mathrm{Cd}$ (see Table III). Secondly, the recoveries of $\mathrm{Pb}$ and $\mathrm{Cd}$ from the soil and leaves fortified with these metals were also used to test the accuracy. It was found that at least $91 \%$ of $\mathrm{Pb}$ and $\mathrm{Cd}$ added to the leaves was recovered, while recoveries up to $95 \%$ and $92 \%$ were obtained for the soil samples, respectively. The levels of $\mathrm{Pb}$ and $\mathrm{Cd}$ in the reagent blanks in the total analytical steps were, respectively, found to be 8.0 and $0.6 \mathrm{ng} \mathrm{mL}^{-1}$ with standard deviations (s) of 2.1 and $0.2 \mathrm{ng} \mathrm{mL}^{-1}$.

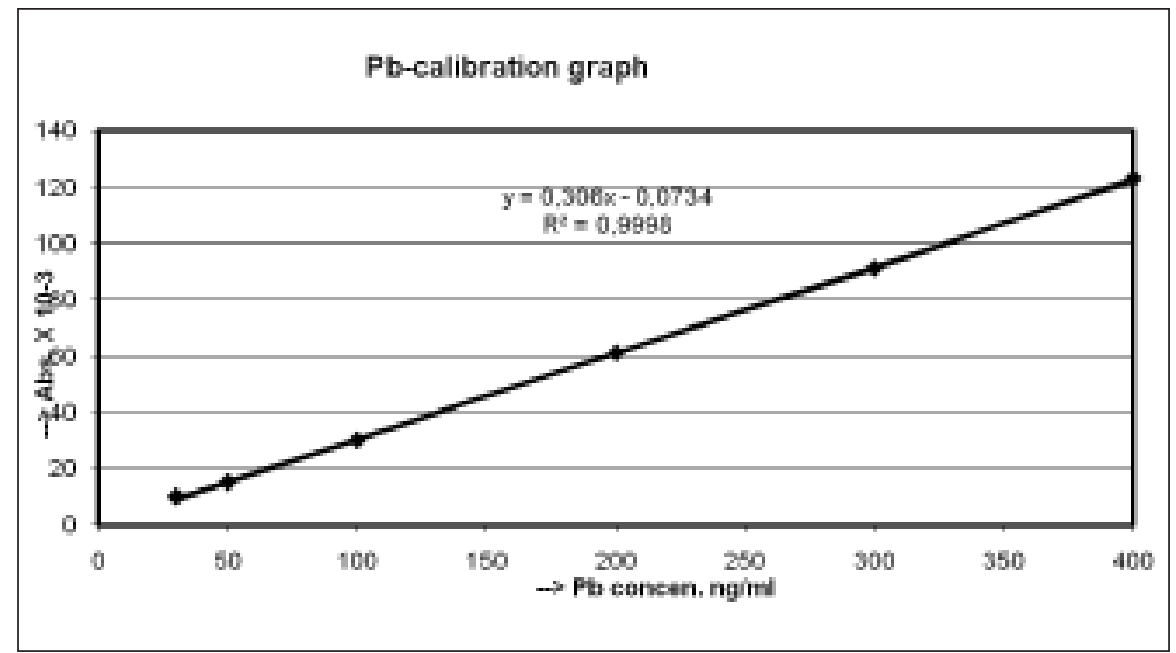

Fig. 2. Calibration curve obtained using STAT-FAAS for Pb determination.

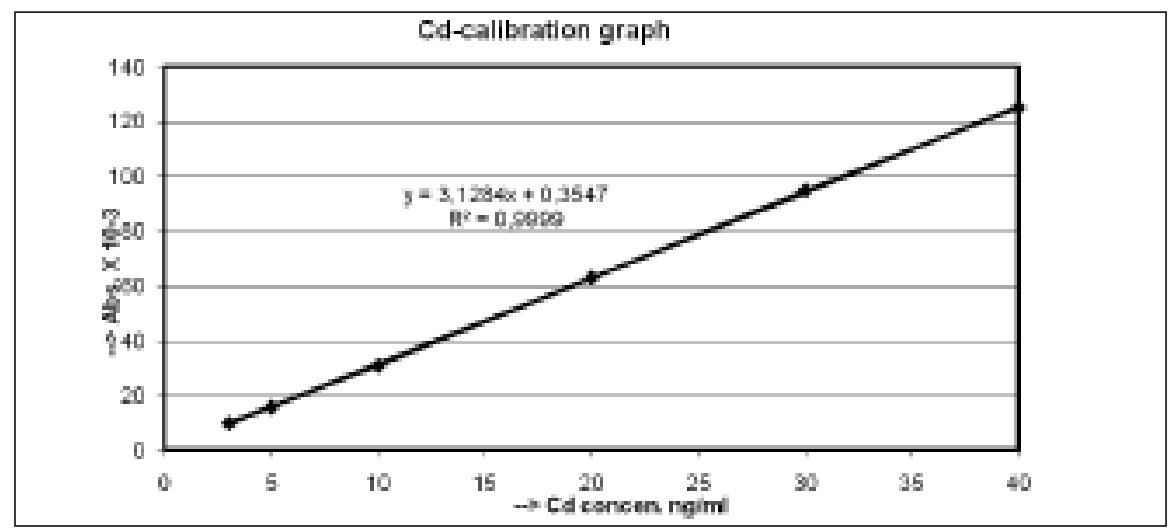

Fig. 3. Calibration curve obtained using STAT-FAAS for Cd determination.

TABLE III

$\mathrm{Pb}$ and $\mathrm{Cd}$ Concentrations in SRM NCSDC73348 Bush Banches and Leaves, and Soil and Leaves

(on dry-weight basis) ( $\mathrm{mg} \mathrm{kg}^{-1}$ )

\begin{tabular}{llll}
\hline & & $\mathrm{Pb}$ & $\mathrm{Cd}$ \\
\hline SRM NCSDC73348 & Certified Value & $7.1 \pm 1.1$ & $0.14 \pm 0.06$ \\
& Found & $6.8 \pm 0.9$ & $0.13 \pm 0.03$ \\
& Recovery & $96 \%$ & $93 \%$ \\
\hline Soil 1 (July) & Added Metal & 5.0 & 0.20 \\
& Found & $14.38 \pm 1.5$ & $0.428 \pm 0.05$ \\
& Recovery & $95 \%$ & $92 \%$ \\
\hline Pinus Nigra L. 1 (July) & Added Metal & 0.2 & 0.020 \\
& Found & $0.518 \pm 0.05$ & $0.0418 \pm 0.006$ \\
& Recovery & $91 \%$ & $91 \%$ \\
\hline
\end{tabular}


Therefore, the limits of detection (LOD), defined as three times of the $s$ values of the blanks, were calculated as 6.3 and $0.6 \mathrm{ng} \mathrm{mL}^{-1}$. The limits of quantitation, defined as 10 times of the s values of blanks, were calculated as 21 and $2.0 \mathrm{ng} \mathrm{mL}^{-1}$. The effects of contamination were eliminated by subtracting the obtained values from the blank. In order to overcome the enhancement or suppression due to the presence of major components such as $\mathrm{Ca}$ and $\mathrm{Mn}$ in the matrices, calibration solutions were performed within the sample matrix itself. On the other hand, the standard additions method for $\mathrm{Pb}$ and $\mathrm{Cd}$ was also applied to check for possible matrix interferences. The slopes of the calibration curves were compared with the slopes obtained for the standard additions method. It was found that the slopes of both methods were the same showing that there were no chemical interferences. Therefore, the calibration curves were used to determine the metal concentrations in the samples. The calibration curves were linear and the concentrations ranged from 200-5000 ng $\mathrm{mL}^{-1} \mathrm{~Pb}$ for FAAS (30-400 $\mathrm{ng} \mathrm{mL}^{-1} \mathrm{~Pb}$ for STAT-FAAS) and 50-500 $\mathrm{ng} \mathrm{mL}^{-1} \mathrm{Cd}$ for FAAS (3-40 ng mL-1 Cd for STAT-FAAS).

\section{$\mathrm{Pb}$ and $\mathrm{Cd}$ Concentrations in Leaves and Soil}

The concentrations of $\mathrm{Pb}$ and $\mathrm{Cd}$ in the leaves of the 3 species taken from 6 locations are listed in Table IV. Each of the samples was analyzed in triplicate and the average of three values was given as the mean value plus standard addition.

Lead and Cd concentrations in the studied soil samples were found in the range of 3.1-10.1 and 0.11-0.51 $\mathrm{mg} \mathrm{kg}^{-1}$, respectively. The observed $\mathrm{Pb}$ and Cd levels in the studied leaves were in the range of $0.14-0.77$ and $<$ LOD$0.057 \mathrm{mg} \mathrm{kg}^{-1}$ for Pinus Nigra L., $0.11-0.91$ and $0.009-0.055 \mathrm{mg} \mathrm{kg}^{-1}$ for Cedrus Libani, and 0.09-0.81 and $<\mathrm{LOD}-0.05 \mathrm{mg} \mathrm{kg}^{-1}$ for Cupressus Arizonica, respectively.

Figures 4-11 show the variation of $\mathrm{Pb}$ and $\mathrm{Cd}$ concentration in the different months of sampling. Figures 5 and 9 show the changes in $\mathrm{Pb}$ and $\mathrm{Cd}$ concentrations of Cedrus Libani depending on sampling location and sampling time, respectively. It was found that $\mathrm{Pb}$ and Cd concentrations in the leaves of Cedrus Libani collected in November and December were higher than in July and March almost for all locations $(\mathrm{p}<0.05)$. These increases can be attributed to the weather and/or temperature conditions. Following the November and December months is the arid summer season and July and March are followed by the rainy winter and spring seasons. Further, it was found that $\mathrm{Cd}$ concentration in leaves from Cedrus Libani collected in July were lower than in other months, except for location 4 .

Figures 4 and 8 show the changes in $\mathrm{Pb}$ and $\mathrm{Cd}$ concentration of Pinus Nigra L. depending on sampling location and sampling time, respectively. It was found that the $\mathrm{Pb}$ concentration in leaves of Pinus Nigra L. in March were lower than in July, November, and December. Figures 6 and 10 show the changes in $\mathrm{Pb}$ and $\mathrm{Cd}$ concentrations of Cupressus Arizonica depending on sampling location and sampling time, respectively.

Briefly, $\mathrm{Pb}$ and $\mathrm{Cd}$ levels in the leaf samples collected in November and December were higher than those in collected in July and March $(\mathrm{p}<0.05)$. Interestingly, the Cd levels in the soil samples from location 4 were higher than in the others $(\mathrm{p}<0.05)$. Lead and Cd concentrations in all studied plants taken from location 4 were higher than in most other locations $(\mathrm{p}<0.05)$. This may be attributed to the fact that location 4 has heavy traffic, although the correlation was not as strong for other locations. In Turkey, unleaded petrol was introduced about 10 years ago. Yet, high $\mathrm{Pb}$ concentrations in heavy traffic areas were still identified because of the long residence time of $\mathrm{Pb}$ in urban soils and active dust re-suspension (22). In addition, the source of $\mathrm{Pb}$ in the soil from the center of the city may be due to corrosion of the metallic parts in cars, such as engine wear, thrust bearing, and brush wear.

The degree of $\mathrm{Pb}$ and $\mathrm{Cd}$ concentrations in the leaves was found to be proportional to industrial and human activities. High metal concentrations in plants located around industrial sites and urban and highway roadsides are due to anthropogenic activities in addition to traffic volume. Based on the $\mathrm{Pb}$ values obtained at the control and other locations, our study concluded that future biomonitoring studies for $\mathrm{Pb}$ contamination would be performed using the leaves of Cedrus Libani.

\section{CONCLUSION}

The advantages of the proposed on-line slotted tube atom trap-flame atomic absorption spectrometry (STAT-FAAS) method are high speed, less risk of contamination, low cost, and easy construction of the required quartz tube. In comparison to off-line enrichment techniques such as solid phase extraction and solvent extraction $(23,24)$, the STAT method is simple and can be easily applied.

In this study, the STAT-FAAS method was used to determine $\mathrm{Pb}$ and $\mathrm{Cd}$ in soils and leaves. Sampling was performed in different months of the year and evaluated based on industry (cement factory), as well as traffic and population density. Based on the $\mathrm{Pb}$ values obtained for the different plant species in the control area and other locations, it was concluded that future Pb biomonitoring studies should be done 


\section{Atomic Spectroscopy \\ 1 Vol. 32(4), July/Augustl 2011}

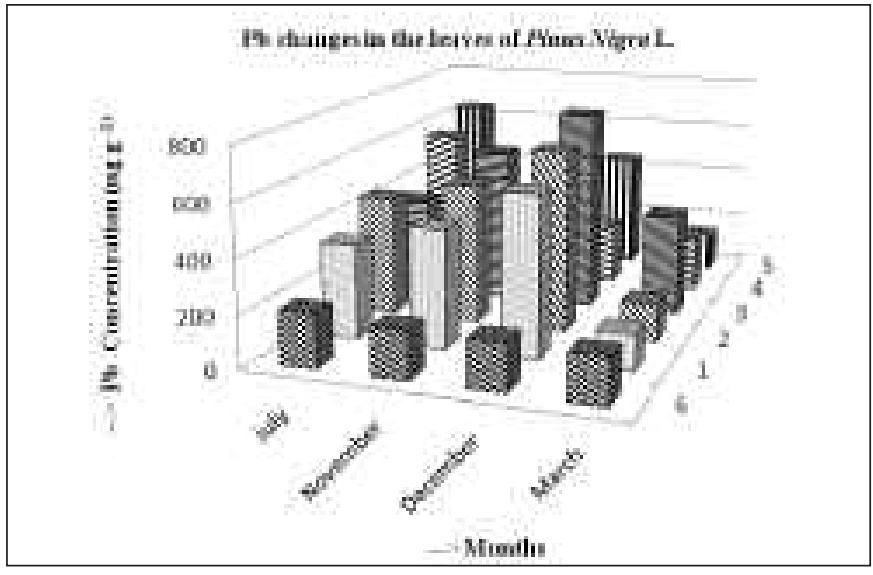

Fig. 4. Pinus Nigra L. leaves. Variation in Pb concentration in different months.

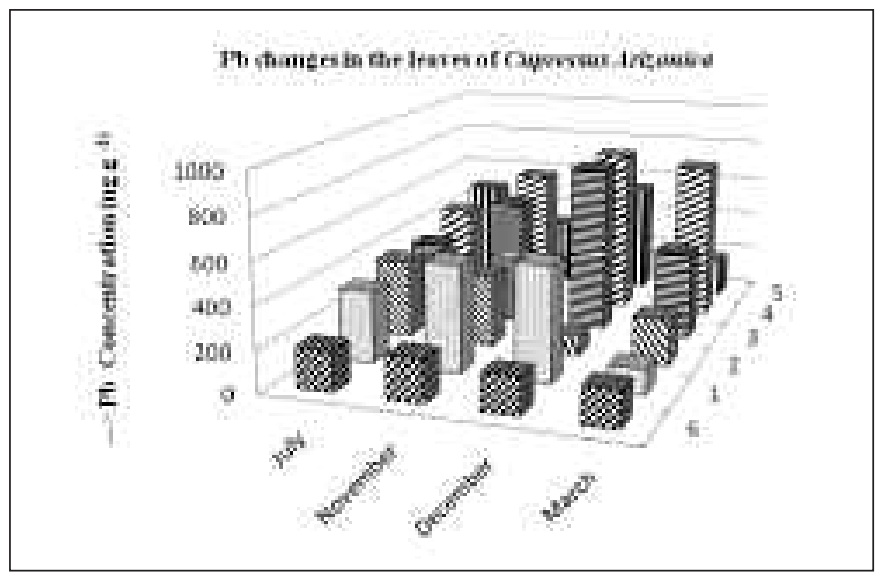

Fig. 6. Cupressus Arizonica leaves. Variation in Pb concentration in different months.

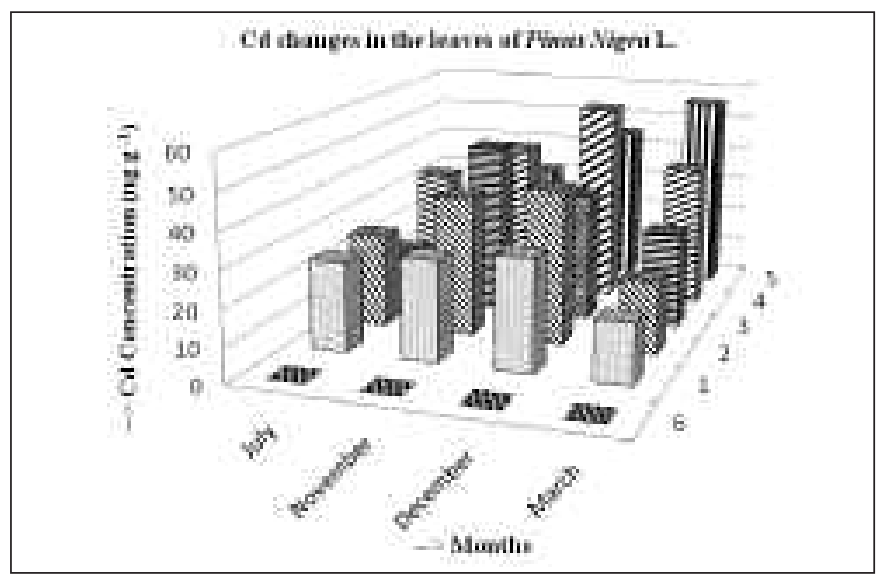

Fig. 8. Pinus Nigra L. leaves. Variation in Cd concentration in different months.

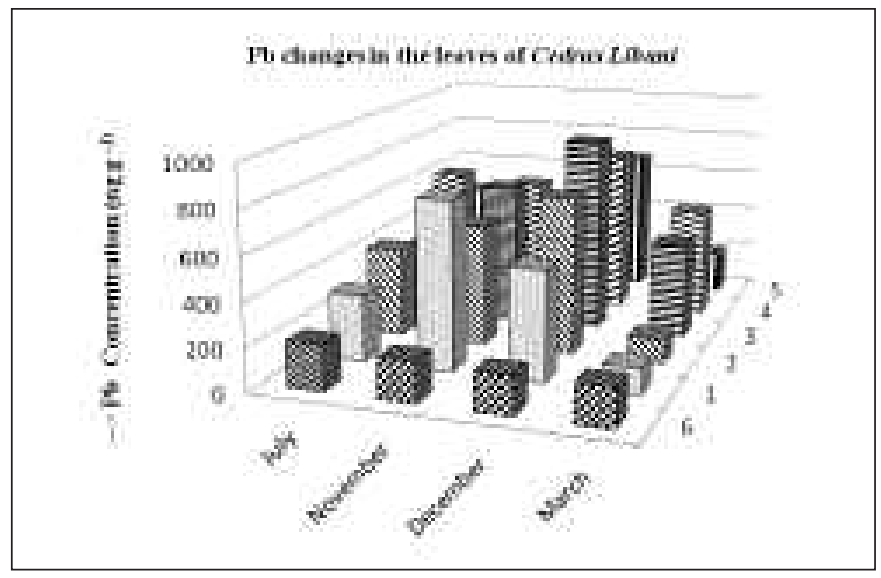

Fig. 5. Cedrus Libani leaves. Variation in Pb concentration in different months.

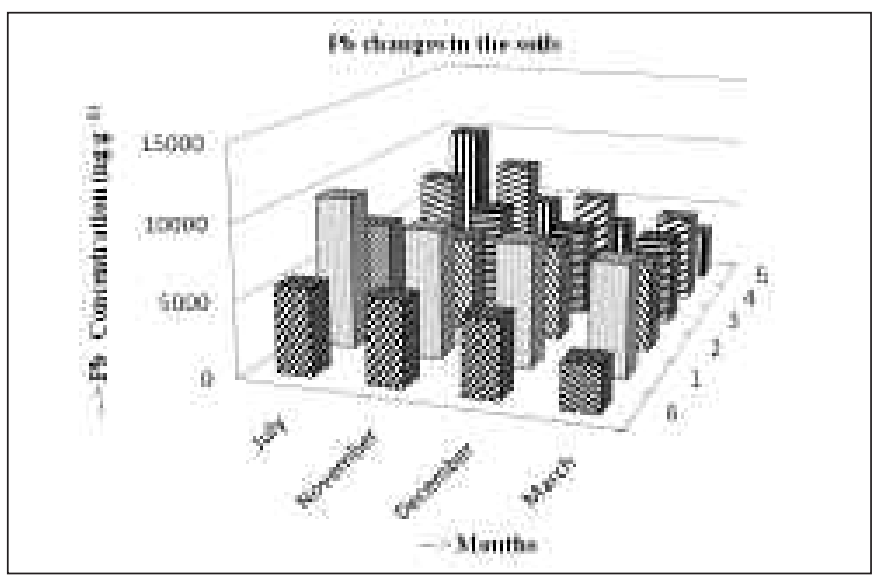

Fig. 7. Soils. Variation in Pb concentration in different months.

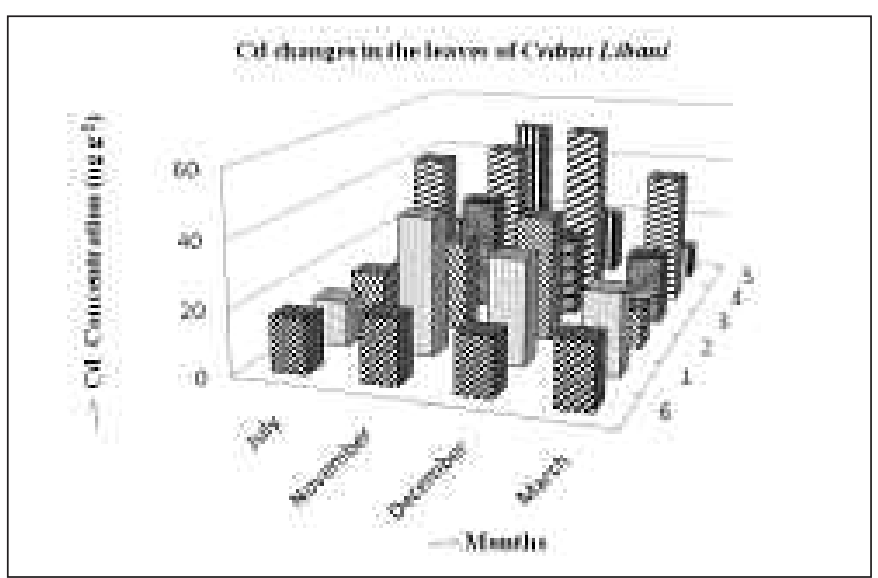

Fig. 9. Cedrus Libani leaves. Variation in Cd concentration in different months. 


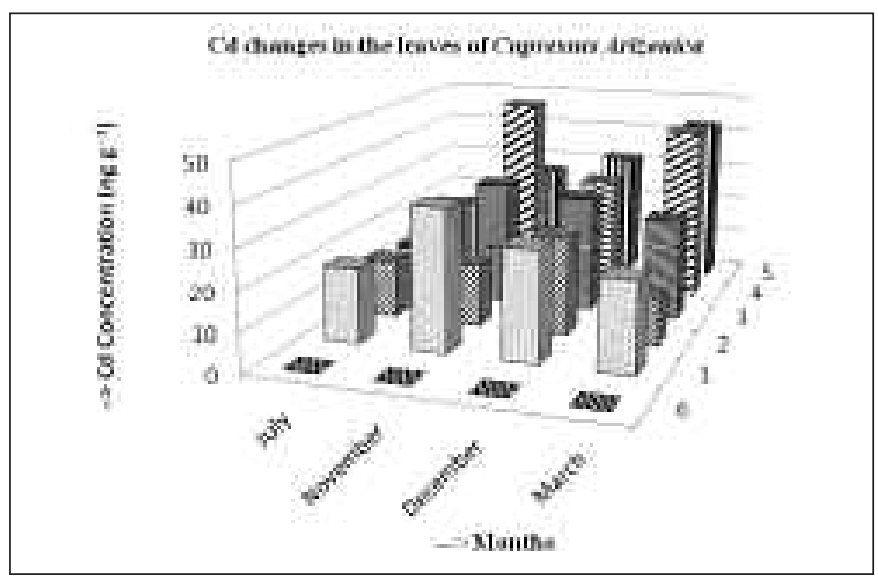

Fig. 10. Cupressus Arizonica leaves. Variation in Cd concentration in different months.

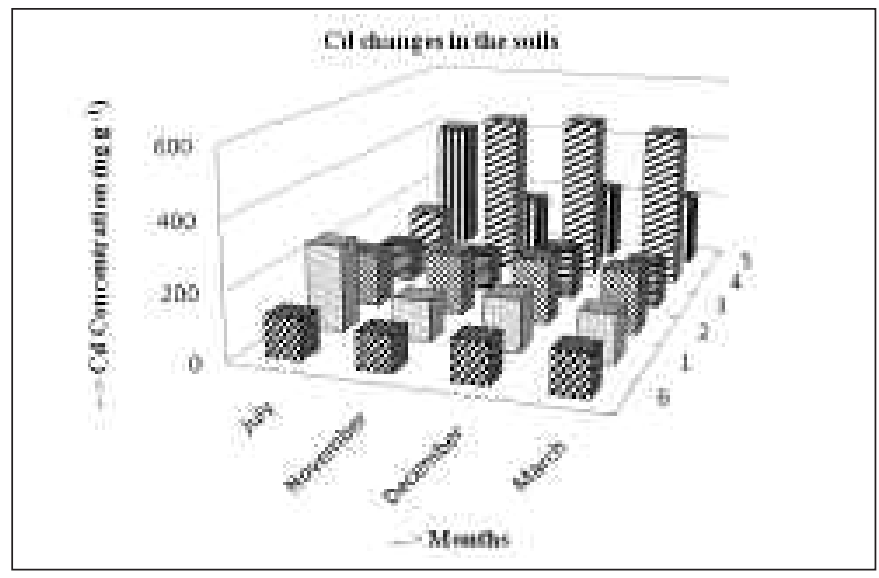

Fig. 11. Soils. Variation in Cd concentration in different months. in regions where the Cedrus Libani species are growing.

The $\mathrm{Pb}$ and $\mathrm{Cd}$ concentrations were found to range from 139$768 \mu \mathrm{g} \mathrm{kg}^{-1}$ and $<\mathrm{LOD}-57$ for Pinus Nigra L., 113-908 $\mathrm{g} \mathrm{kg} \mathrm{k}^{-1}$ and 9-55 $\mu \mathrm{g} \mathrm{kg}^{-1}$ for Cedrus Libani, and 88- $813 \mu \mathrm{g} \mathrm{kg}^{-1}$ and <LOD$50 \mu \mathrm{g} \mathrm{kg}-1$ for Cupressus Arizonica. The levels observed for $\mathrm{Pb}$ and $\mathrm{Cd}$ in the soils ranged from 3100-10112 $\mu \mathrm{g} \mathrm{kg}^{-1}$ and 106$505 \mu \mathrm{g} \mathrm{kg}^{-1}$, respectively.

The $\mathrm{Pb}$ and $\mathrm{Cd}$ concentrations in the leaves of these plants growing in Elazig, Turkey, were found to be below the phytotoxic level of $30 \mathrm{mg} \mathrm{kg}^{-1}$ for $\mathrm{Pb}$ and the permissible level of $3 \mathrm{mg} \mathrm{kg}^{-1}$ for Cd.

Received April 13, 2011.

\section{REFERENCES}

1. S. J. S. Flora, J. Environ. Biol. 23, 25 (2002).

2. G. F. Nordberg, Biometals 17, 485 (2004).

3. M. Yaman, Curr. Med. Chem. 13, 2513 (2006).

4. WHO (World Health Organization), Fifty-Third Report of the Joint FAO/WHO Expert Committee on Food Additives, WHO Technical
Report Series 896, Geneva, Switzerland (2000).

5. A. Mulgrew and P. Williams, in: Biomonitoring of air quality using plants. Air Hygiene Report No. 10, Berlin, Germany, WHO CC, 165 pp (2000).

6. B. A. Markert, A. M. Breure, and H. G. Zechmeister, in: Bioindicators and Biomonitors: Principles, Concepts and Applications, Elsevier, Amsterdam, The Netherlands (2003).

7. R. Bargagli, Plants as Biomonitors, in: Trace elements in terrestrial plants: an ecophysiological approach to biomonitoring and biorecovery, Springer Verlag, Berlin-HeidelbergNew York (1998).

8. M. Tomasevic, S. Rajsic, D. Dordevic, M. Tasic, J. Krstic, and V. Novakovic, Environ. Chem. Lett. 2, 151 (2004).

9. G. Kaya and M. Yaman, Trace Elem. and Electrolyt. 25(3), 156 (2008).

10. G. Kaya and M. Yaman, Talanta 75 , 1127 (2008).

11. J. Mertens, S. Luyssaert, and K. Verheyen, Environ. Pollut. 138, 1 (2005).

12. B. Smodis, M. L. Pignata, M. Saiki, E. Cortes, N. Bangfa, B. Markert, and B. Nyarko, J. Atm. Chem. 49(1-3), 3 (2004).

13. J. R. Aboal, J.A. Fernandez, and A. Carballeira, Environ. Exp. Bot. 51, 215 (2004).
14. P. Madejon, T. Maranon, and J. M. Murillo, Sci. Total Environ. 355, 187 (2006).

15. O. Kaplan and M. Yaman, At. Spectrosc. 30(1), 1 (2009).

16. G. Kaya, C. Ozcan, and M. Yaman, Bull. Environ. Contam. Toxicol. 84(2), 191 (2010).

17. IARC, Cadmium and Cadmium Compounds. In: IARC Monographs on the evaluation of carcinogenic risks to humans, Volume 58, Beryllium, cadmium, mercury, and exposures in the glass manufacturing industry, Lyon, France (1993).

18. J. Azcue and A. Mudroch, Inter. J. Environ. Anal. Chem. 57, 151 (1994).

19. M. Yaman, Anal. Biochem. 339, 1 (2005).

20. V. D. Zheljazkov and P. McNeil, J. Plant Nutr. 31, 1937 (2008).

21. M. Yaman and S. Gucer, Analyst 120, 101 (1995).

22. S. Bakirdere and M. Yaman, Environ. Monitor. Assess. 136, 401 (2008).

23. M. Yaman, Spectrosc. Lett. 34, 763 (2001).

24. M. Yaman and G. Kaya, Anal. Chim. Acta 540, 77 (2004). 


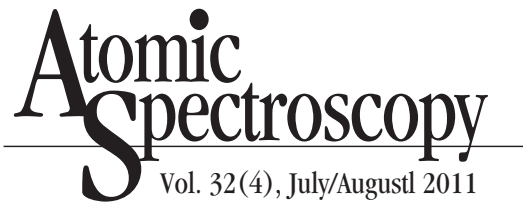

TABLE IV

Metal Concentrations in Soil and Leaves From 6 Locations in Elazig, Turkey

Values are $\mathrm{ng} \mathrm{g}^{-1}$ for $\mathrm{Pb}$ and $\mathrm{Cd}$ (on dry-weight basis);

Results are mean values \pm standard deviation, $n=3$

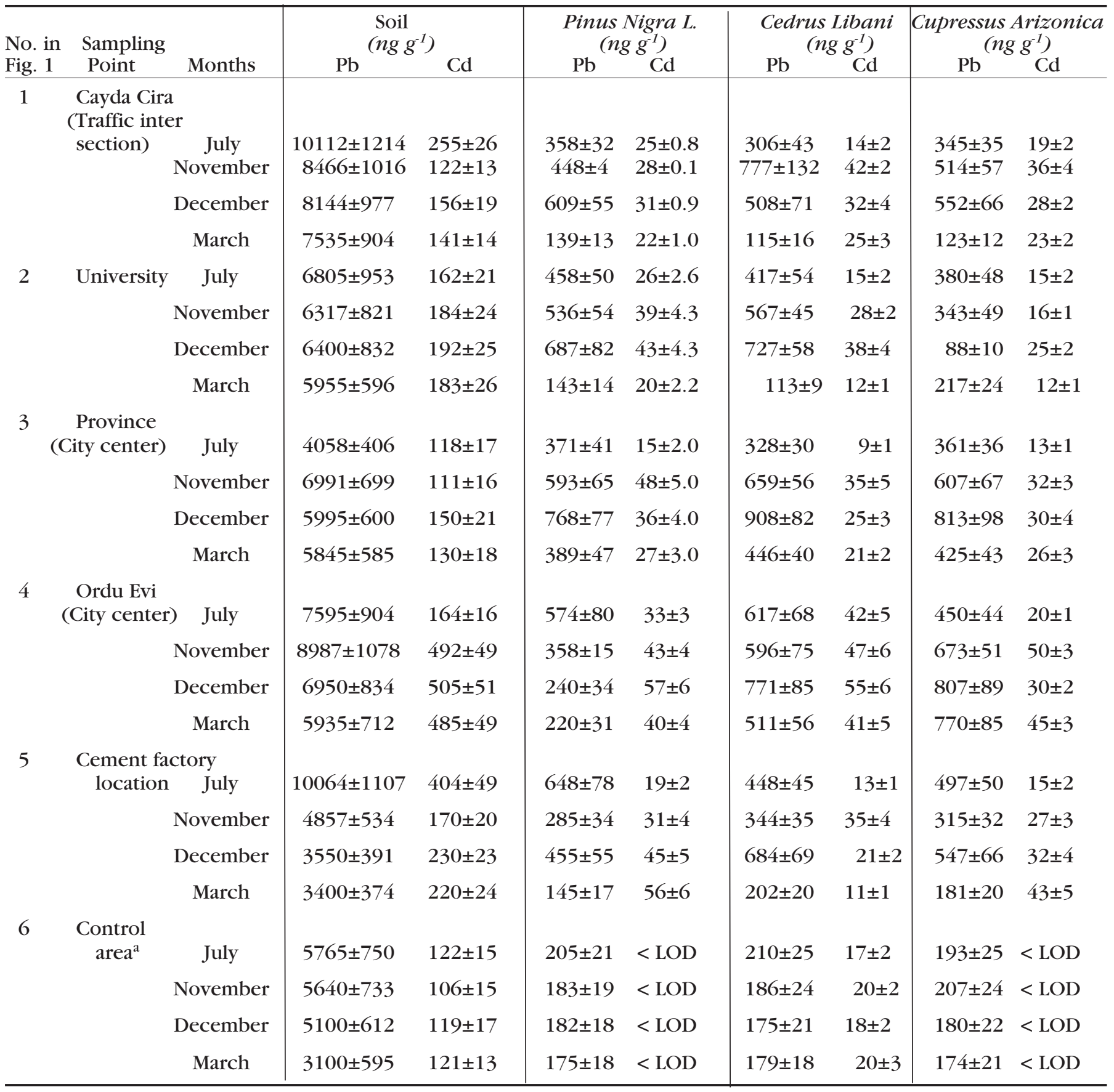

LOD: Limit of detection.

${ }^{a}$ Away from residential areas and factories. 